\title{
Penerapan Hukum terhadap Anak sebagai Pelaku Tindak Pidana Pencurian dengan Kekerasan
}

\section{Application of the Law against Children as a Violent Crime}

\author{
Friwina Magnesia Surbakti \& Rizkan Zulyadi \\ Jurusan Ilmu Hukum, Fakultas Hukum, Universitas Medan Area, Indonesia
}

Diterima: Mei 2019; Disetujui: Juli 2019; Dipublish: Agustus 2019

*Coresponding Email: Friwinamagnesia @gmail.com

\begin{abstract}
Abstrak
Penelitian ini difokuskan terhadap bagaimana Penerapan Hukum terhadap Anak sebagai pelaku tindak pidana pencurian dengan kekerasan yang dikerucutkan terhadap Undang-undang Nomor 11 Tahun 2012 tentang Sistem Peradilan Pidana Anak (SPPA) dan Kitab Undang-undang Hukum Pidana (KUHP). Penelitian ini menggunakan Metode Penelitian Normatif yaitu penelitian yang objek kajiannya meliputi norma atau kaidah dasar, asas-asas hukum, peraturan perundang-undangan, perbandingan hukum, doktrin, serta yurisprudensi. Jenis data yang digunakan adalah data sekunder yaitu data yang diperoleh dari kepustakaan (library research) perpustakaan Fakultas Hukum Universitas Medan Area. Penelitian ini bersifat deskriptif Analitis, yaitu menganalisa, menggambarkan, menelaah dan menjelaskan secara tepat serta menganalisis peraturan perundang-undangan yang berkaitan dengan Penerapan Hukum Terhadap Anak Sebagai Pelaku Tindak Pidana Pencurian Studi Kasus Putusan Nomor: 42/Pid.Sus-Anak 2017/PN.MDN. Pertimbangan memiliki tujuan pemidanaan berupa pembalasan, pencegahan (Prevensi), keadilan masyarakat dan perlindungan terhadap kepentingan Anak Pelaku Tindak Pidana Pencurian Dengan Kekerasan. Penerapan hukum terhadap Muhammad Hadji Als Aji, telah sesuai dengan Ketentuan Kitab Undang-Undang Hukum Acara Pidana dan Undang-undang Nomor 11 Tahun 2012 Tentang Sistem Peradilan Pidana Anak. Dimana anak dapat mempertanggungjawabkan perbuatannya dan haknya sebagai anak pelaku tindak pidana yang dijamin dalam Undang-undang Nomor 11 Tahun 2012 tentang Sistem Peradilan Pidana Anak telah dipenuhi.
\end{abstract}

Kata Kunci: Penerapan, Anak Pelaku Tindak Pidana, Tindak Pidana Pencurian dengan Kekerasan.

\begin{abstract}
This research is focused on how the application of the law against children as perpetrators of theft with violence that is pursed against Law Number 11 of 2012 concerning the Child Criminal Justice System (SPPA) and the Criminal Code (KUHP). This research uses the Normative Research Method which is the study of which the object of study includes basic norms or principles, legal principles, statutory regulations, legal comparisons, doctrines, and jurisprudence. The type of data used is secondary data that is data obtained from the library (library research) library of the Faculty of Law, University of Medan Area. This research is analytical descriptive, that is analyzing, describing, analyzing and explaining precisely and analyzing the laws and regulations relating to the Application of Laws Against Children as Perpetrators of Crime Theft Case Study Verdict Number: 42 / Pid.Sus-Anak 2017 / PN. MDN. Consideration has the aim of criminal offenses in the form of retaliation, prevention (Prevention), community justice and protection of the interests of Children of Violent Crimes. The application of the law against Muhammad Hadji Als Aji, is in accordance with the provisions of the Criminal Procedure Code and Law Number 11 of 2012 concerning the Juvenile Justice System. Where the child can be held accountable for his actions and his rights as a child of a criminal offense guaranteed in Law Number 11 of 2012 concerning the Child Criminal Justice System have been fulfilled.
\end{abstract}

Keywords: Implementation, Children of Criminal Acts, Theft of Violent Crimes.

How to Cite: Surbakti, F.M. \& Zulyadi, R. (2019). Penerapan Hukum terhadap Anak sebagai Pelaku Tindak Pidana Pencurian dengan Kekerasan. Journal of Education, Humaniora, and Social Sciences (JEHSS), 2 (1): 143-166. 


\section{PENDAHULUAN}

Anak menurut Pasal 1 angka 1 Undang-undang Nomor 35 Tahun 2014. Tentang Perubahan Atas Undang-undang Nomor 23 Tahun 2002 tentang Perlindungan Anak adalah seseorang yang belum berusia 18 (delapan belas) tahun dan bahkan masih dalam kandungan. Berdasarkan Pasal 21 Ayat (2) Undang-undang Nomor 35 Tahun 2014 Tentang Perubahan Atas Undang-undang Nomor 23 Tahun 2002 tentang Perlindungan Anak,tegas dikatakan bahwa Anak haruslah dilindungi haknya dan negara berkewajiban untuk memenuhi, melindungi, dan menghormati hak anak.

Anak memiliki hak untuk mendapatkan perlindungan, perhatian, kasih sayang, dan pendidikan demi kesejahteraan anak tersebut. Anak harus mendapat perlindungan khusus terhadap kepentingan fisik dan mentalnya. Diharapkan agar anak dapat bertumbuh kembang dengan baik dan anak terlindungi dari ancaman kejahatan yang membahayakan dirinya. Perlindungan hak-hak anak pada hakikatnya menyangkut langsung pengaturan dalam peraturan perundang- undangan, kebijaksanaan, usaha dan kegiatan yang menjamin terwujudnya perlindungan hak-hak anak, pertama-tama didasarkan atas pertimbangan bahwa anak-anak merupakan golongan yang rawan dan independen, disamping karena adanya golongan anak-anak yang mengalami hambatan dalam pertumbuhan dan perkembangannya, baik rohani, jasmani, maupun sosial. (Waluyadi, 2009)

Kejahatan adalah perilaku yang dilarang oleh negara, karena merupakan perbuatan yang merugikan negara dan terhadap perbuatan itu negara bereaksi dengan hukuman sebagai upaya pamungkas (Ultimum Remedium). Kejahatan juga sudah merambat terhadap kalangan anak-anak. Bukan hanya Anak sebagai korban kekerasan yang terjadi terhadap anak, yang paling memprihatinkan sekarang bahwa ketika anak itu sendiri yang menjadi pelaku tindak pidana. (Gultom, 2006).

Banyak sekali fenomena yang diberitakan oleh media massa bahwa anak menjadi pelaku tindak pidana pencurian dengan kekerasan. Anak sebagai sosok yang lemah dan tidak berdaya tentu belum memahami apa yang baik dan buruk untuk dilakukan. Tindak pidana yang dilakukan oleh anak dimulai dari sikap menyimpang anak dari norma-norma masyarakat yang cenderung mengarah ke tindak pidana atau sering disebut sebagai Juvenil Deliquency. (Kusumaningrum, 2014). 
Tindak pidana anak (Juvenil Deliquency) merupakan salah satu masalah urgen pemerintah dalam menanggulangi tindak pidana di Indonesia. Seyogianya Anak adalah bagian yang tak terpisahkan dari keberlangsungan hidup manusia, bangsa dan negara. Dalam konstitusi Indonesia, anak memiliki peran strategis yang secara tegas dinyatakan bahwa negara menjamin hak setiap anak atas kelangsungan hidup, tumbuh dan berkembang serta berhak atas perlindungan dari kekerasan dan diskriminasi, sebagaimana dijelaskan dalam UUD 1945 Pasal 28 B ayat 2.

Anak merupakan suatu elemen penting negara, maka terhadap Tindak Pidana anak Konstitusi Indonesia membentuk Undang-undang Nomor 11 tahun 2012 tentang Sistem Peradilan Pidana Anak dengan pertimbangan: a) Bahwa anak merupakan amanah dan karunia Tuhan Yang Maha Esa yang memiliki harkat dan martabat sebagai manusia seutuhnya; b) Bahwa untuk menjaga harkat dan martabat, anak berhak mendapatkan perlindungan khusus,terutama perlindungan hukum dalam sistem peradilan; c) Bahwa Indonesia sebagai Negara pihak dalam konvensi hak-hak anak (Conventional on the Rights of the Child) yang mengatur prinsip perlindungan hukum terhadap anak mempunyai kewajiban untuk memberikan perlindungan hukum terhadap anak mempunyai kewajiban untuk memberikan perlindungan khusus hukum terhadap anak yang berhadapan hukum; d) Bahwa Undang-undang Nomor 3 Tahun 1997 tentang pengadilan anak sudah tidak sesuai lagi dengan perkembangan dan kebutuhan hukum masyarakat karena belum secara komperenshif memberikan perlindungan kepada anak yang berhadapan dengan hukum sehingga perlu diganti dengan undang-undang baru; e) Bahwa berdasarkan pertimbangan sebagaimana dimaksud dalam huruf a, b, c, dan huruf d, perlu membentuk undang-undang tentang sistem peradilan anak.

Undang-Undang Nomor 11 Tahun 2012 Tentang Sistem Peradilan Pidana Anak mempertegas tentang pengertian anak di dalam Pasal 1 Angka (3) disebutkan bahwa: “Anak yang Berkonflik dengan Hukum yang selanjutnya disebut Anak adalah anak yang telah berumur 12 (dua belas) tahun, tetapi belum berumur 18 (delapan belas) tahun yang diduga melakukan tindak pidana. Undang-undang tentang Pengadilan Anak melihat sisi anak dari perbuatan yang dilakukannya, apabila anak tersebut melakukan kejahatan sebelum anak tersebut umur 12 (dua belas) tahun tidak dikategorikan anak nakal sehingga dari sisi hukum ia belum dapat dimintai pertanggungjawaban, sebaliknya apabila sudah mencapai umur 12 (dua belas) tahun sampai 18 (delapan belas) tahun 
dapat dimintai pertanggungjawaban atas perbuatan yang dilakukannya, kemudian bila anak tersebut sebelum umur 18 (delapan belas) tahun sudah kawin maka bukan dikategorikan anak dan proses peradilan melalui peradilan umum bukan peradilan anak."

Undang-Undang Nomor 11 Tahun 2012 Tentang Sistem Peradilan Pidana bertujuan memberikan yang terbaik bagi anak, tanpa mengorbankan kepentingan masyarakat dan tegaknya suatu keadilan. Tujuan Peradilan Anak tidak berbeda dengan peradilan lainnya, yaitu memeriksa, memutus dan menyelesaikan perkara anak. Dalam hal ini, pelaksanaan pembinaan dan perlindungan terhadap anak, diperlukan dukungan baik yang menyangkut kelembagaan maupun perangkat hukum yang lebih baik dan mewadahi.

Fenomena kejahatan anak di Indonesia akhir-akhir ini menunjukan gejala yang sangat mengkhawatirkan. Banyaknya peristiwa-peristiwa tawuran pelajar, pencurian, pemerkosaan, narkoba, seks bebas, miras, bolos sekolah dan perilaku-perilaku menyimpang lain menunjukan bukti bahwa Juvenile Deliquency perlu mendapat perhatian serius dari semua kalangan.

Fakta-fakta tersebut menunjukan bahwa kenakalan anak bukan hanya merupakan gangguan terhadap keamanan dan ketertiban masyarakat semata- mata, akan tetapi juga merupakan bahaya yang dapat mengancamkan masa depan masyarakat suatu bangsa. Anak sebagai salah satu sumber daya manusia, merupakan potensi penerus bangsa perlu mendapatkan pengawasan dan bimbingan supaya tidak terjerumus kedalam kenakalan remaja serius ataupun melakukan perbuatan melanggar hukum (Kartono,1992),

Undang-Undang Nomor 11 Tahun 2012 Tentang Sistem Peradilan Pidana Anak memberikan kekhususan dalam Due Procces Law bagi pelaku Tindak Pidana Anak yang dikenal dengan Diversi. Diversi menurut UU No.11 Tahun 2012 telah diberikan tafsiran autentik pada Pasal 1 Angka 7, yaitu pengalihan penyelesaian perkara anak dari proses peradilan pidana ke proses diluar peradilan pidana. Kekhususan dalam upaya penyelesaian tindak pidana anak tidak semata-mata untuk membedakan penyelesaian tindak pidana, namun lebih kepada upaya penyelamatan generasi bangsa yang terjebak dalam kenakalan.

Fenomena sosial yang terjadi bahwa tindak pidana yang dilakukan oleh anak (Juvenile delinquency) dewasa ini juga terjadi di berbagai daerah, salah satunya terjadi di wilayah hukum Pengadilan Negeri Medan. Salah satu tindak pidana yang marak terjadi adalah tindak pidana pencurian dengan kekerasan. 
Tindak pidana pencurian dengan kekerasan ini sering sekali terjadi tidak pandang siapa korban, baik laki-laki maupun perempuan, anak hingga orang dewasa dan kapan waktu dilakukan. Oleh karena ketertarikan Penulis terhadap Tindak pidana pencurian dengan kekerasan yang dilakukan oleh anak, Penulis kemudian mengangkat Putusan Perkara Pidana Pengadilan Negeri Medan Nomor: 42/PID.SUS-ANAK 2017/PN-MDN sebagai objek penelitian ini.

\section{METODE PENELITIAN}

Metode penelitian dalam penulisan skripsi ini yaitu Metode penelitian normatif. Penelitian normatif yang dimaksud yaitu penelitian yang objek kajiannya meliputi norma atau kaidah dasar, asas-asas hukum, peraturan perundang-undangan, perbandingan hukum, doktrin, serta yurisprudensi. (Amiruddin \& Asikin, 2004).

Jenis data yang digunakan dalam penelitian ini adalah data sekunder yaitu data yang diperoleh dari kepustakaan. Penelitian ini bersifat deskriptif Analitis, artinya bahwa penelitian ini termasuk lingkup penelitian yang menganalisa, menggambarkan, menelaah dan menjelaskan secara tepat serta menganalisis peraturan perundang-undangan yang berkaitan dengan Penerapan Hukum Terhadap Anak Sebagai Pelaku Tindak Pidana Pencurian Studi Kasus Putusan Nomor : 42/Pid.Sus-Anak 2017/PN.MDN. Penelitian ini bersifat deskriptif analitis oleh karena penelitian ini akan menggambarkan dan melukiskan azas-azas atau peraturan-peraturan yang berhubungan dengan tujuan penelitian ini.

Untuk melengkapi dan menunjang penyelesaian penelitian Lokasi penelitian yang diambil dalam penyelesaian penelitian ini adalah Pengadilan Negeri Medan. Alasan pengambilan lokasi penelitian didasarkan atas Putusan Nomor: 42/Pid.Sus-Anak 2017/PN.MDN dikeluarkan oleh Pengadilan Negeri Medan. Sehingga data yang diambil akan akurat dan akuntabel.

Teknik pengumpulan data ada dua jenis, yakni pengumpulan data dengan Penelitian Lapangan (Field Research) dan pengumpulan data dengan penelitian kepustakaan (Library Research). Teknik pengumpulan data dengan penelitian lapangan (Field Research) merupakan salah satu metode pengumpulan data dalam penelitian kualitatif yang tidak memerlukan pengetahuan mendalam akan literatur yang digunakan dan kemampuan tertentu dari pihak peneliti. Penelitian lapangan biasa dilakukan untuk memutuskan ke 
arah mana penelitiannya berdasarkan konteks. Penelitian lapangan biasa diadakan di luar ruangan.

Dalam penelitian ini Penulis menggunakan metode pengumpulan data kepustakaan atau Library research. (Sunggono, 1995). Penelitian yang dilakukan dengan cara meneliti dokumen - dokumen dari bahan pustaka atau yang disebut dengan data sekunder yaitu putusan pengadilan, peraturan perundang-undangan, buku-buku baik koleksi pribadi maupun dari perpustakaan, artikel-artikel baik yang diambil dari media cetak maupun media elektronik, makalah ilmiah, dan bahan-bahan lain yang berhubungan dengan materi yang akan dibahas dalam penelitian ini.

Metode yang digunakan untuk menganalisis data adalah analisis kualitatif, yaitu data yang diperoleh kemudian disusun secara sistematis dan selanjutnya dianalisis secara kualitatif untuk mencapai kejelasan masalah yang akan dibahas dan hasilnya tersebut dituangkan dalam bentuk artikel ini.

Penggunaan metode analisis kualitatif didasarkan pada berbagai pertimbangan yakni pertama, analisis di dasarkan pada paradigma hubungan yang dinamis antara teori, konsep dan data yang merupakan umpan balik atau modifikasi yang tetap dari teori dan konsep yang didasarkan pada data yang dikumpulkan. Kedua, data yang di analisis beraneka ragam serta memiliki sifat dasar yang berbeda antara yang satu dengan yang lain dan ketiga, sifat dasar data yang akan di analisis dalam penelitian adalah bersifat menyeluruh dan merupakan satu kesatuan yang intergral (holistic) yang menuntut tersedianya informasi yang mendalam (indepth information). (Siregar, 2005).

Data yang telah terkumpul dianalisis secara kualitatif yakni dengan mengadakan pengamatan data-data yang diperoleh dan menghubungkan tiap-tiap data tersebut dengan ketentuan-ketentuan maupun asas-asas hukum yang terkait dengan permasalahan yang diteliti. Penelitian ini adalah penelitian yuridis normatif yang bersifat kualitatif yakni penelitian yang mengacu pada norma hukum yang terdapat dalam peraturan perundang-undangan dan putusan pengadilan serta norma-norma yang hidup dan berkemabang dalam masyarakat. (Amali, 2014). Karena penelitian ini normatif, dilakukan interprestasi dan kontruksi hukum dengan menarik kesimpulan menggunakan cara deduktif adalah yakni dengan pemikiran dimulai dari hal yang umum kepada hal yang khusus. (Arifin, 2011). Hal ini dilakukan untuk menjawab dari permasalahan dan tujuan penelitian yang ditetapkan sehingga mengetahui 
Bagaimanakah Penerapan Hukum Terhadap Anak Sebagai Pelaku Tindak Pidana Pencurian.

\section{HASIL DAN PEMBAHASAN}

\section{Penyebab Terjadinya Tindak Pidana Pencurian Dengan Kekerasan Yang Dilakukan} Oleh Anak

Untuk melihat lebih jelas mengapa anak cenderung melakukan kejahatan/kenakalan maka perlu untuk mengetahui faktor-faktor terjadinya kejahatan anak. Adapun faktor terjadinya kejahatan anak dapat dilihat dari 2 (dua) macam, yaitu: (Mubarak dan Trisna, 2012): 1) Motivasi Intrinsik, yaitu: a. Faktor Intelegentia (kecerdasan), b. Faktor usia c. Faktor kelamin, d.Faktor kedudukan anak dalam keluarga; 2) Motivasi Ekstrinsik, yaitu: a. Faktor rumah tangga, b. Faktor pendidikan dan sekolah, c. Faktor pergaulan anak, d.Faktor mass media.

Menurut UU No. 11 tahun 2012 tentang Sistem Peradilan Pidana Anak, yang dimaksud dengan anak yang berhadapan dengan hukum adalah anak yang berkonflik dengan hukum, anak yang menjadi korban tindak pidana, dan anak yang menjadi saksi tindak pidana. Ketentuan ini disebutkan dalam Pasal 1 nomor 2. Berdasarkan definisi ini dapat disebutkan bahwa terdapat tiga kategori anak yang berhadapan dengan hukum, yaitu: 1) Anak yang berkonflik dengan hukum. Maksudnya adalah anak sebagai pelaku tindak pidana; 2) Anak yang menjadi korban tindak pidana, yaitu anak yang mengalami penderitaan fisik, mental, dan/kerugian ekonomi yang disebabkan oleh tindak pidana; 3) Anak yang menjadi saksi tindak pidana, yaitu anak yang dapat memberikan keterangan guna kepentingan penyidikan, penuntutan, dan pemeriksaan di sidang pengadilan tentang suatu perkara pidana yang didengar, dilihat, dan/atau dialaminya sendiri.

Kategori anak sebagai pelaku tindak pidana tentu saja memiliki ketentuan umur tersendiri. Mereka adalah anak yang telah berumur 12 (dua belas) tahun, tetapi belum berumur 18 (delapan belas) tahun yang diduga melakukan tindak pidana. Jadi anak yang berumur di bawah 12 tahun, walaupun melakukan tindak pidana, belum dikategorikan sebagai anak yang berhadapan dengan hukum. Dengan demikian, ia berada di luar ketentuan ini. Begitu juga, orang yang telah berumur di atas 18 tahun tidak lagi digolongkan kepada anak, namun sudah dianggap dewasa, dan berlaku ketentuan umum hukum pidana. 
Terdapat sepuluh asas yang diterapkan dalam sistem peradilan anak berdasarkan pasal 2 UU No. 11 tahun 2012, yaitu: a) Perlindungan, Yang dimaksud dengan "pelindungan" meliputi kegiatan yang bersifat langsung dan tidak langsung dari tindakan yang membahayakan Anak secara fisik dan/atau psikis. b) Keadilan, Yang dimaksud dengan "keadilan" adalah bahwa setiap penyelesaian perkaraAnak harus mencerminkan rasa keadilan bagi Anak. c) Nondiskriminasi, Yang dimaksud dengan "nondiskriminasi" adalah tidak adanya perlakuan yang berbeda didasarkan pada suku, agama, ras, golongan, jenis kelamin, etnik, budaya dan bahasa, status hukum Anak, urutan kelahiran Anak, serta kondisi fisik dan/atau mental. d) Kepentingan terbaik bagi anak, Yang dimaksud dengan"kepentingan terbaik bagi Anak" adalah segala pengambilan keputusan harus selalu mempertimbangkan kelangsungan hidup dan tumbuh kembang Anak. e) Penghargaan terhadap pendapat anak, Yang dimaksud dengan "penghargaan terhadap pendapat Anak" adalah penghormatan atas hak Anak untuk berpartisipasi dan menyatakan pendapatnyadalam pengambilan keputusan, terutama jika menyangkut hal yang memengaruhi kehidupan anak. f) Kelangsungan hidup dan tumbuh kembang anak Yang dimaksud dengan "kelangsungan hidup dan tumbuh kembang Anak" adalah hak asasi yang paling mendasar bagi Anak yang dilindungi oleh negara, pemerintah, masyarakat, keluarga, dan orang tua. g) Pembinaan dan pembimbingan Anak, Yang dimaksud dengan "pembinaan" adalah kegiatan untuk meningkatkan kualitas, ketakwaan kepada Tuhan Yang Maha Esa, intelektual, sikap dan perilaku, pelatihan keterampilan, profesional, serta kesehatan jasmani dan rohani Anak baik di dalam maupun di luar proses peradilan pidana. Yang dimaksud dengan "pembimbingan" adalah pemberian tuntunan untuk meningkatkan kualitas ketakwaan kepada Tuhan Yang Maha Esa, intelektual, sikap dan perilaku, pelatihan keterampilan, profesional, serta kesehatan jasmani dan rohani klien pemasyarakatan. h) Proporsional, Yang dimaksud dengan "proporsional" adalah segala perlakuan terhadap Anak harus memperhatikan batas keperluan, umur, dan kondisi Anak. i) Perampasan kemerdekaan dan pemidanaan sebagai upaya terakhir, Yang dimaksud dengan "perampasan kemerdekaan merupakan upaya terakhir" adalah pada dasarnya Anak tidak dapat dirampas kemerdekaannya, kecuali terpaksa guna kepentingan penyelesaian perkara. j)Penghindaran pembalasan. Yang dimaksud dengan "penghindaran pembalasan" adalah prinsip menjauhkan upaya pembalasan dalam proses peradilan pidana. 
Asas-asas yang ada tersebut secara jelas menunjukkan perlakuan khusus terhadap anak yang berhadapan dengan hukum. Asas pertama, misalnya, menekankan asas perlindungan terhadap anak. Perlindungan ini didasarkan pada keadaan pelaku yang masih anak-anak yang tidak bisa disamakan dengan orang dewasa. Selanjutnya, huruf d menyebutkan agar proses hukum yang dilakukan mengacu kepada kepentingan terbaik bagi anak, untuk kelangsungan hidup dan tumbuh kembang anak, dan seterusnya. Berdasarkan asas- asas ini pula, maka diperlukan aturan dan tindakan khusus untuk menangani perkara anak.

\section{Penerapan Hukum Terhadap Anak Sebagai Pelaku Tindak Pidana Pencurian Dengan Kekerasan}

Tujuan Penerapan Hukum Terhadap Anak Sebagai Pelaku Tindak Pidana Pencurian Dengan Kekerasan Dalam Putusan Nomor: 42/Pid.Sus Anak/2017/PN.Mdn. Tujuan penerapan hukum dapat dilihat dari Out put atau hasil dari penerapan hukum itu sendiri. Tujuan penerapan hukum dapat dilihat dari beberapa teori pemidanaan.

Teori tujuan sebagai Theological Theory dan teori gabungan sebagai pandangan integratif di dalam tujuan pemidanaan beranggapan bahwa pemidanaan mempunyai tujuan pliural, di mana kedua teori tersebut menggabungkan pandangan Utilitarian dengan pandangan Retributivist. Pandangan Utilitarian yang menyatakan bahwa tujuan pemidanaan harus menimbulkan konsekuensi bermanfaat yang dapat dibuktikan dan pandangan retributivist yang menyatakan bahwa keadilan dapat dicapai apabila tujuan yang Theological tersebut dilakukan dengan menggunakan ukuran prinsip-prinsip keadilan.

Menurut Pellegrino Rossi dalam bukunya "Traite de Droit Penal" yang ditulis pada tahun 1828 menyatakan: „Sekalipun pembalasan sebagai asas dari pidanabahwa beratnya pidana tidak boleh melampaui suatu pembalasan yang adil, namun pidana mempunyai berbagai pengaruh antara lain perbaikan sesuatu yang rusak dalam masyarakat dan prevensi general, terhadap teori gabungan ini terdapat tiga aliran yang mempengaruh, yaitu: a) Teori gabungan yang menitik beratkan unsur pembalasan, tetapi sifatnya yang berguna bagi masyarakat. Pompe menyebutkan dalam bukunya "Hand boek van het Ned Strafrecht" bahwa pidana adalah suatu sanksi yang memiliki ciri-ciri tersendiri dari sanksi lain dan terikat dengan tujuan dengan sanksi-sanksi tersebut karenanya akan diterapkan jika menguntungkan pemenuhan kaidah-kaidah yang berguna bagi kepentingan 
umum; b) Teori gabungan yang menitik beratkan pertahan tata tertib masyarakat. Pembalasan adalah sifat suatu pidana tetapi tujuannya adalah melindungi kesejahteraan masyarakat; c). Teori gabungan yang memandang sama pembalasan dan pertahanan tata tertib masyarakat.

Begitu pula Roeslan Saleh mengemukakan, bahwa pidana hakekatnya terdapat dua poros yang menentukan garis-garis hukum pidana yaitu: 1) Segi Prevensi, yaitu bahwa hukum pidana adalah hukum sanksi, suatu upaya untuk dapat mempertahankan kelestarian hidup bersama dengan melakukan pencegahan kejahatan. 2) Segi Pembalasan, yaitu bahwa hukum pidana sekaligus merupakan pula penentu hukum, merupakan koreksi dan reaksi atas sesuatu yang bersifat tidak hukum. Pada hakekatnya pidana selalu melindungi masyarakat dan pembalasan atas perbuatan tidak hukum. Selain itu Roeslan Saleh juga mengemukakan bahwa pidana mengandung hal-hal lain, yaitu bahwa pidana diharapkan sebagai suatu yang akan membawa kerukunan serta sebagai suatu proses pendidikan untuk menjadikan orang dapat diterima kembali dalam masyarakat. Jadi memang sudah seharusnyalah tujuan pidana adalah membentuk kesejahteraan Negara dan masyarakat yang tidak bertentangan dengan norma kesusilaan dan perikemanusiaan sesuai dengan Pancasila.

Keempat adalah Teori Integratif, Teori Integratif ini diperkenalkan oleh Muladi, guru besar dari Fakultas HukumUniversitas Diponegoro. Dewasa ini masalah pemidanaan menjadi sangat kompleks sebagai akibat dari usaha untuk lebih memperhatikan faktorfaktor yang menyangkut hak-hak asasi manusia, serta menjadikan pidana bersifat operasional dan fungsional.Untuk ini diperlukan pendekatan multi dimensional yang bersifat mendasar terhadap dampak pemidanaan, baik yang menyangkut dampak yang bersifat individual maupun dampak yang bersifat sosial.

Pendekatan semacam ini mengakibatkan adanya keharusan untuk memilih teori integratif tentang tujuan pemidanaan, yang dapat memenuhi fungsinya dalam rangka mengatasi kerusakan-kerusakan yang diakibatkan oleh tindak pidana (individual and social damages). Pemilihan teori integratif tentang tujuan pemidanaan ini didasarkan atas alasan-alasan, baik yang bersifat sosiologis, ideologis, maupun yuridis. Alasan secara sosiologis dapat dilihat pada pendapat yang dikemukakan oleh Stanley Grupp, bahwa kelayakan suatu teori pemidanaan tergantung pada anggapan-anggapan seseorang terhadap hakekat manusia, informasi yang diterima seseorang sebagaiilmu pengetahuan 
yang bermanfaat, macam dan luas pengetahuan yang mungkin dicapai dan penilaian terhadap persyaratan-persyaratan untuk menerapkan teori-teori tertentu serta kemungkinan-kemungkinan yang dapat dilakukan untuk menemukan persyaratanpersyaratan tersebut. Alasan secara ideologis, dengan mengutip pendapat Notonagoro, menyatakan: Berdasarkan Pancasila, maka manusia ditempatkan pada keseluruhan harkat dan martabatnya sebagai mahluk Tuhan Yang Maha Esa dengan kesadaran untuk mengembangkan kodratnya sebagai mahluk pribadi dan sekaligus sosial. Pancasila yang bulat dan utuh itu memberi keyakinanan kepada rakyat dan bangsa Indonesia bahwa kebahagiaan hidup akan tercapai apabila di dasarkan atas keselarasan dan keseimbangan, baik dalam hidup manusia dengan alam, dalam hubungannya dengan bangsa lain, dalam hubungan manusia dengan Tuhannya, maupun dalam mengejar kemajuan lahirlah dan kebahagiaan rohani.

Berdasarkan alasan-alasan sosiologis, ideologi dan, Muladi menyimpulkan sebagai berikut: Dengan demikian, maka tujuan pemidanaan adalah untuk memperbaiki kerusakan individual dan sosial (individual and social damages) yang diakibatkan oleh tindak pidana. Hal ini terdiri dari seperangkat tujuan pemidanaan yang harus dipenuhi, dengan catatan bahwa tujuan manakah yang merupakan titik berat sifatnya kasuitis. Perangkat tujuan pemidanaan yang dimaksud diatas adalah: a. Pencegahan (umum dan khusus); b. Perlindungan Masyarakat; c. Memelihara Solidaritas Masyarakat dan d. Pengimbalan/Pengimbangan.

Dari beberapa teori tujuan pemidanaan di atas, Penulis melihat keseluruhan teori diatas telah terpenuhi sebagai pertimbangan hakim dalam memutuskan hukuman terhadap Anak atau Terdakwa Muhamad Hadji Alias Aji. Hal ini dapat Penulis simpulkan sebab dalam pertimbangannya Majelis Hakim mempertimbangkan bahwa oleh karena Terdakwa telah terbukti secara sah dan meyakinkan bersalah melakukan tindak pidana dan tindakan terdakwa dapat dipertanggung jawabkan kepada terdakwa, maka terdakwa haruslah dijatuhi hukuman yang setimpal dengan kesalahan tersebut serta memenuhi rasa keadilan dengan memperhatikan manfaatnya, baik dari segi prevensi ataupun keseimbangan perlindungan terhadap masyarakat dan perlindungan terhadap kepentingan terdakwa.

Dalam pertimbangan tersebut dapat disimpulkan bahwa tujuan penerapan hukum terhadap Anak Sebagai Pelaku Tindak Pidana Pencurian Dengan Kekerasan Dalam 
Putusan Nomor: 42/Pid.Sus Anak/2017/PN.Mdn antara lain yakni tujuan pemidanaan pembalasan, tujuan pemidanaan pencegahan (prevensi), tujuan pemidanaan keadilan masyarakat dan tujuan pemidanaan perlindungan terhadap kepentingan Anak atau Terdakwa.

\section{Analisa Putusan Tentang Penerapan Hukum}

Berdasarkan pasal yang didakwakan dalam Surat Dakwaan berbentuk dakwaan tunggal oleh penuntut umum yang juga telah dituangkan dalam tuntutan Jaksa Penuntut Umum yang menuntut bersalah Muhammad Hadji Als Aji dengan tuntutan hukuman penjara selama 2 (dua) tahun serta dalam vonis hukuman yang dijatuhkan Majelis Hakim pemeriksa putusan nomor : 42/PID.SUS-ANAK 2017/PN-MDN ini telah sesuai dengan ketentuan-ketentuan pidana dalam KUHPidana, yakni melanggar Pasal 365 ayat (2) ke-1 dan ke-2 KUHPidana yaitu tindak pidana pencurian dengan kekerasan yang dilakukan oleh anak.

Rumusan surat dakwaan telah sesuai dengan hasil pemeriksaan pada tahap penyidikan yang kemudian diajukan dalam persidangan. Tuntutan Jaksa Penuntut Umum telah sesuai dengan Pasal-pasal yang dipersangkakan kepada Terdakwa Muhammad Hadji Als Aji dan dikuatkan dengan fakta-fakta yang terungkap dipersidangan. Hal ini dikarenakan Terdakwa benar telah terbukti dimuka persidangan dengan berdasarkan keterangan saksi-saksi dan fakta-fakta hukum bahwa perbuatan terdakwa telah memenuhi unsur- unsur dalam 365 ayat (2) ke-1 dan ke-2 KUHPidana. Majelis Hakim pemeriksa putusan nomor : 42/PID.SUS-ANAK 2017/PN-MDN berdasarkan pertimbangan bahwa dakwaan yang telah sesuai dan tuntutan Jaksa Penuntut Umum yang terbukti telah menjatuhkan vonis bersalah kepada Terdakwa, Muhammad Hadji Als Aji dengan pidana penjara selama 2 (dua) tahun.

Berdasarkan pertimbangan tersebut penulis berpendapat bahwa penerapan hukum terhadap Muhammad Hadji Als Aji, anak yang berhadapan dengan hukum sebagai pelaku tindak pidana pencurian dengan kekerasan telah sesuai dengan Ketentuan Kitab UndangUndang Hukum Acara Pidana dan Undang-undang Nomor 11 Tahun 2012 Tentang Sistem Peradilan Pidana Anak. Dimana anak dapat mempertanggungjawabkan perbuatannya dan haknya sebagai anak pelaku tindak pidana yang dijamin dalam Undang-undang Nomor 11 Tahun 2012 tentang Sistem Peradilan Pidana Anak telah dipenuhi dalam Putusan 42/PID.SUS-ANAK 2017/PN-MDN. 


\section{Pertimbangan Hakim dalam Menjatuhkan Hukuman terhadap Anak}

Putusan adalah pernyataan hakim yang dituangkan dalam bentuk tertulis dan diucapkan oleh hakim dalam sidang terbuka untuk umum sebagai hasil pemerikasaan perkara gugatan (kontentius).

Ada berbagai jenis Putusan Hakim dalam pengadilan dari segi fungsinya dalam mengakhiri perkara putusan hakim adalah sebagai berikut: Pertama adalah Putusan akhir. Putusan akhir adalah putusan yang mengakhiri pemeriksaan di persidangan, baik telah melalui semua tahap pemeriksaan maupun tidak/belum menempuh semua tahap pemeriksaan. Putusan yang dijatuhkan sebelum tahap akhir dari tahap-tahap pemeriksaan, tetapi telah mengakhiri pemeriksaan yaitu: 1. Putusan gugur, 2. Putusan verstek yang tidak diajukan verzet, 3. Putusan tidak menerima 4. Putusan yang menyatakan pengadilan agama tidak berwenang memeriksa semua putusan akhir dapat dimintakan akhir, kecuali bila undang-undang menentukan lain.

Kedua adalah Putusan Sela, Putusan sela merupakan putusan yang dijatuhkan masih dalam proses pemeriksaan perkara dengan tujuan untuk memperlancar jalannya pemeriksaan. Putusan sela tidak mengakhiri pemeriksaan, tetapi akan berpengaruh terhadap arah dan jalannya pemeriksaan. Putusan sela dibuat seperti putusan biasa, tetapi tidak dibuat secara terpisah, melainkan ditulis dalam berita acara persidangan saja.

Putusan sela harus diucapkan di depan sidang terbuka untuk umum serta ditanda tangani oleh majelis hakim dan penitera yang turut bersidang. Putusan sela selalu tunduk pada putusan akhir karena tidak berdiri sendiri dan akhirnya dipertimbangkan pula pada putusan akhir. Hakim tidak terkait pada putusan sela, bahkan hakim dapat merubahnya sesuai dengan keyakinannya. Putusan sela tidak dapat dimintakan banding kecuali bersama-sama dengan putusan akhir. Para pihak dapat meminta supaya kepadanya diberi salinan yang sah dari putusan itu dengan biaya sendiri.

Kemudian putusan hakim dalam acara pidana terbagi menjadi tiga macam putusan yaitu: Pertama adalah Putusan Bebas (Pasal 191 ayat (1) KUHAP, Putusan bebas merupakan putusan paengadilan yang di jatuhkan kepada terdakwa karena dari hasil pemeriksaan sidang kesalahan terdakwa atas perbuatan yang di dakwakan kepadanya dinyatakan tidak terbukti secara sah dan meyakinkan. Selanjutnya dalam Pasal 191 ayat (1) KUHAP dijelaskan bahwa yang dimaksud dengan perbuatan yang didakwakan 
kepadanya tidak terbukti secara sah dan meyakinkan adalah tidak cukup terbukti menurut penilaian hakim atas dasar pembuktian dengan menggunakan alat bukti menurut ketentuan hukum acara pidana.

Dari ketentuan tersebut di atas, berarti putusan bebas ditinjau dari segi yuridis ialah putusan yang dinilai oleh majelis hakim tidak memenuhi atas pembuktian menurut undang-undang secara negatif, artinya dari pembuktian yang diperoleh di persidangan, tidak cukup membuktikan kesalahan terdakwa dan hakim tidak yakin atas kesalahan terdakwa yang tidak cukup terbukti itu. Selain itu juga tidak memenuhi-memenuhi asas batas minimum pembuktian, artinya kesalahan yang didakwakan kepada terdakwa hanya didukung oleh satu alat bukti saja, sedangkan menurt ketentuan Pasal 183 KUHAP, agar cukup membuktikan kesalahan seorang terdakwa, harus dibuktikan dengan sekurang-kurangnya dua alat bukti yang sah (Harahap, 2005).

Kedua adalah Putusan Lepas dari segala tuntutan hukum, merupakan putusan yang dijatuhkan kepada terdakwa yang setelah melalui pemeriksaan ternyata menurut pendapat pengadilan, perbuatan yang didakwakan kepada terdakwa terbukti, tetapi perbuatan itu tidak merupakan satu tindak pidana (Pasal 191 ayat (2) KUHAP. Jenis putusan ini dasar hukumnya dapat ditemukan dalam Pasal 191 ayat (2) KUHAP yang menyebutkan: "Jika pengadilan berpendapat bahwa perbuatan yang didakwakan kepada terdakwa terbukti, tetapi perbuatan itu tidak merupakan suatu tindak pidana, maka terdakwa di putus lepas dari segala tuntutan".

Ketiga adalah Putusan yang mengandung pemidanaan, merupakan putusan yang membebankan suatu pidana kepada terdakwa karena perbuatan yang didakwakan terbukti secara sah dan meyakinkan bahwa terdakwa bersalah melakukan perbuatan yang didakwakan itu.(Pasal 193 ayat (1) KUHAP. dasar putusan ini adalah Pasal 193 ayat (3) KUHAP yang berbunyi: "Jika pengadilan berpendapat bahwa terdakwa bersalah melakukan tindak pidana yang didakwakan kepadanya, maka pengadilan menjatuhkan pidana".

Pertimbangan Hakim atau Ratio Decidendi adalah argumen atau alasan yang dipakai oleh hakim sebagai pertimbangan hukum yang menjadi dasar sebelum memutus perkara. Pertimbangan hakim merupakan salah satu aspek terpenting dalam menentukan terwujudnya nilai dari suatu putusan hakim yang mengandung keadilan (exaequo et bono) dan mengandung kepastian hukum, disamping itu juga mengandung manfaat bagi 
para pihak yang bersangkutan sehingga pertimbangan hakim ini harus disikapi dengan teliti, baik, cemat. Apabila pertimbangan hakim tidak teliti, baik, dan cermat, maka putusan hakim yang berasal dari pertimbangan hakim tersebut akan dibatalkan oleh Pengadilan Tinggi/Makamah Agung.

Sebagai hakim dalam hal menjatuhkan pidana kepada terdakwa tidak boleh menjatuhkan pidana tersebut kecuali apabila dengan sekurang-kurangnya dua alat bukti yang sah sebagai pertimbangannya, sehingga hakim memperoleh keyakinan bahwa suatu tindak pidana benar-benar terjadi dan terdakwalah yang bersalah melakukannya (Pasal 183 KUHAP). Alat bukti sah yang dimaksud adalah: a. Keterangan Saksi; b. Keterangan Ahli; c. Surat; d. Petunjuk; e. Keterangan Terdakwa atau hal yang secara umum sudah diketahui sehingga tidak perlu dibuktikan (Pasal 184 KUHAP) (Satjipto Rahardjo, 1998).

Pasal 185 ayat (2) KUHAP menyebutkan bahwa keterangan seorang saksi saja tidak cukup untukmembuktikan bahwa terdakwa bersalah terhadap perbuatan yang didakwakan kepadanya, sedangkan dalam ayat 3 dikatakan ketentuan tersebut tidak berlaku apabila disertai dengan suatu alat bukti yang sah lainnya (unus testis nullus testis). Saksi korban juga berkualitas sebagai saksi, sehingga apabila terdapat alat bukti yang lain sebagaimana dimaksud dalam ayat 3 KUHAP,maka hal itu cukup untuk menuntut pelaku tindak pidana (Satjipto Rahardjo, 1998).

Menurut Pasal 53 Undang-Undang Nomor 48 Tahun 2009 tentang Kekuasaan Kehakiman: a) Dalam memeriksa dan memutus perkara, hakim bertanggung jawab atas penetapan dan putusan yang dibuatnya. b) Penetapan dan putusan sebagaimana dimaksud pada ayat (1) harus memuat pertimbangan hukum hakim yang didasarkan pada alasan dan dasar hukum yang tepat dan benar.

Hakim Pengadilan Negeri mengambil suatu keputusan dalam sidang pengadilan, mempertimbangkan beberapa aspek, yaitu: a) Kesalahan pelaku tindak pidana Hal ini merupakan syarat utama untuk dapat dipidananya seseorang. Kesalahan di sini mempunyai arti seluas-luasnya, yaitu dapat dicelanya pelaku tindak pidana tersebut. Kesengajaan dan niat pelaku tindak pidana harus ditentukan secara normatif dan tidak secara fisik. Untuk menentukan adanya kesengajaan dan niat harus dilihat dari peristiwa demi peristiwa, yang harus memegang ukuran normatif dari kesengajaan dan niat adalah hakim. b). Motif dan tujuan dilakukannya suatu tindak pidana kasus tindak pidana 
mengandung unsur bahwa perbuatan tersebut mempunyai motif dan tujuan untuk dengan sengaja melawan hokum. c. Cara melakukan tindak pidana pelaku melakukan perbuatan tersebut ada unsur yang direncanakan terlebih dahulu untuk melakukan tindak pidana tersebut. Memang terapat unsur niat di dalamnya yaitu keinginan sipelaku untuk melawan hukum. d. Sikap batin pelaku tindak pidana Hal ini dapat diidentifikasikan dengan melihat pada rasa bersala, rasa penyesalan dan berjanji tidak akan mengulangi perbuatan tersebut. Pelaku juga memberikan ganti rugi atau uang santunan pada keluarga korban dan melakukan perdamaian secara kekeluargaan. e. Riwayat hidup dan keadaan sosial ekonomi Riwayat hidup dan keadaan sosial ekonomi pelaku tindak pidana juga sangat mempengaruhi putusan hakim yaitu dan memperingan hukuman bagi pelaku, misalnya belum pernah melakukan perbuatan tidak pidana apa pun, berasal dari keluarga baikbaik, tergolong dari masyarakat yang berpenghasilan sedang- sedang saja (kalangan kelas bawah).f. Sikap dan tindakan pelaku sesudah melakukan tindak pidana Pelaku dalam dimintai keterangan atas kejadian tersebut, ia menjelaskan tidak berbelit-belit, ia menerima dan mengakui kesalahannya. Maka hal yang di atas juga menjadi pertimbangan bagi hakim untuk memberikan keringanan pidana bagi pelaku. Karena hakim melihat pelaku berlaku sopan dan mau bertanggung jawab, juga mengakui semua perbuatannya dengan cara berterus terang dan berkata jujur. Karena akan mempermudah jalannya persidangan. g. Pengaruh pidana terhadap masa depan pelaku Pidana juga mempunyai tujuan yaitu selain membuat jera kepada pelaku tindak pidana, juga untuk mempengaruhi pelaku agar tidak mengulangi perbuatannya tersebut, membebaskan rasa bersalah pada pelaku, memasyarakatkan pelaku dengan mengadakan pembinaan, sehingga menjadikannya orang yang lebih baik dan berguna. h. Pandangan masyarakat terhadap tindak pidana yang dilakukan oleh pelaku Dalam suatu tindak pidana masyarakat menilai bahwa tindakaan pelaku adalah suatu perbuatan tercela, jadi wajar saja kepada pelaku untuk dijatuhi hukuman, agar pelaku mendapatkan ganjarannya dan menjadikan pelajaran untuk tidak melakukan perbuatan yangdapat merugikan diri sendiri dan orang lain. Hal tersebut dinyatakan bahwa ketentuan ini adalah untuk menjamin tegaknya kebenaran, keadilan dan kepastian hukum. i Pasal 8 ayat (2) Undang-undang Nomor 48 Tahun 2009 Tentang Kekuasaan Kehakiman Juncto Pasal 197 ayat (1) huruf f KUHAP, mewajibkan hakim untuk mempertimbangkan hal-hal yang 
memberatkan dan meringankan hukuman terdakwa yang ditemukan dan digali selama proses persidangan.

Pasal 8 ayat (2) Undang-undang Nomor 48 Tahun 2009 Tentang Kekuasaan Kehakiman berbunyi: "Dalam mempertimbangkan berat ringannya pidana, hakim wajib memperhatikan pula sifat yang baik dan jahat dari terdakwa."

Pasal 197 ayat (1) huruf f KUHAP berbunyi : "Pasal peraturan perundang-undangan yang menjadi dasar pemidanaan atau tindakan dan pasal peraturan perundangundangan yang menjadi dasar hukum dari putusan, disertai keadaan yang memberatkan dan yang meringankan terdakwa" Dalam Putusan Nomor : 42/Pid.SusAnak/2017/PN.Mdn, Majelis Hakim memberikan pertimbangan bahwa Anak atau terdakwa bersikap sopan dan mengakui perbuatannya sebagimana dalam dakwaan Jaksa Penuntut Umum serta Anak atau terdakwa belum pernah dihukum.

Sikap sopan yang dilakukan Anak juga merupakan tindakan yang tidak menghambat jalannya persidangan sehingga sangat perlu dipertimbangkan utuk meringankan hukuman sedangkan sikap Anak atau terdakwa yang mengakui perbuatannya merupakan penyesalan Anak terhadap perbuatannya yang melakukan tindak pidana pencurian dengan kekerasan.

Dalam Putusan Nomor: 42/Pid.Sus-Anak/2017/PN.Mdn, Majelis Hakim memberikan pertimbangan yang memberatkan bahwa: 1) Perbuatan Anak meresahkan masyarakat Pertimbangan ini merupakan pertimbangan utama atau Ultimum Remedium atau obat terakhir atas tindak pidana yang dilakukan anak. Pertimbangan ini yang memenjarakan anak telah sesuai dengan ketentuan Pasal 81 ayat (1) Undang-undang Nomor 11 Tahun 2012 Tentang Sistem Peradilan Pidana Anak yang mengharuskan, penjatuhan pidana penjara di LPKA apabila keadaan dan perbuatan Anak akan membahayakan masyarakat; 2) Perbuatan Anak telah merugikan orang lain. Pertimbangan ini didasarkan atas akibat dari perbuatan Anak atau terdakwa melakukan pencurian dengan kekerasan kepada korban Sugeng Raharjo sehingga korban mengalami kerugian berkisar Rp. 8.350.000,- (Delapan Juta Tiga Ratus Lima Puluh Ribu Rupiah).

Berdasarkan posisi kasus sebagaimana telah diuraikan diatas, maka dapat disimpulkan bahwa dakwaan Penuntut Umum, tuntutan Penuntut Umum, dan pertimbangan hakim pengadilan dalam amar putusannya telah memenuhi unsur dan syarat dipidananya terdakwa. Hal ini didasarkan pada pemeriksaan dalam persidangan 
dimana alat bukti yang diajukan oleh Penuntut Umum termasuk didalamnya keterangan saksi-saksi dan keterangan terdakwa yang saling berhubungan antara satu dengan yang lainnya. Keterangan terdakwa yang mengakui secara jujur perbuatan yang telah dilakukannya dan menyesalinya. Oleh karena itu, Hakim Pengadilan Negeri Medan menyatakan dalam amar putusannya bahwa terdakwa telah terbukti secara sah dan meyakinkan melakukan tindak pidana pencurian dengan kekerasan sebagaimana diatur dalam Pasal 365 ayat (2) ke-1dan ke-2 KUHPidana dan menghukum terdakwa dengan pidana penjara selama 2 (dua) tahun.

Dalam menjatuhkan putusan, Hakim menjatuhkan tindakan pidana kepada anak sebagai pendidikan untuk membimbing anak agar tidak kembali mengulangi perbuatan pidana yang dapat merugikan orng lain dan anak itu sendiri. Tujuan dari hukuman itu sendiri untuk mendidik dan memperbaiki orang-orang yang sudah melakukan kejahatan, agar menjadi orang yang lebih baik, sehinga sanksi tindakan sangat tepat untuk dijatuhkan kepada Anak.

\section{SIMPULAN}

Penerapan hukum terhadap Muhammad Hadji Als Aji, anak yang berhadapan dengan hukum sebagai pelaku tindak pidana pencurian dengan kekerasan telah sesuai dengan Ketentuan Kitab Undang- Undang Hukum Acara Pidana dan Undang-undang Nomor 11 Tahun 2012 Tentang Sistem Peradilan Pidana Anak. Dimana anak dapat mempertanggungjawabkan perbuatannya dan haknya sebagai anak pelaku tindak pidana yang dijamin dalam Undang-undang Nomor 11 Tahun 2012 tentang Sistem Peradilan Pidana Anak telah dipenuhi dalam Putusan 42/PID.SUS-ANAK 2017/PN-MDN.

Pertimbangan hakim didasarkan pada pemeriksaan dalam persidangan dimana alat bukti yang diajukan oleh Penuntut Umum termasuk di dalamnya keterangan saksi-saksi dan keterangan terdakwa yang saling berhubungan antara satu dengan yang lainnya. Keterangan terdakwa yang mengakui secara jujur perbuatan yang telah dilakukannya dan menyesalinya. Sehingga Majelis Hakim Pengadilan Negeri Medan menyatakan dalam amar putusannya bahwa terdakwa telah terbukti secara sah dan meyakinkan melakukan tindak pidana pencurian dengan kekerasan sebagaimana diatur dalam Pasal 365 ayat(2) ke-1dan ke-2 KUHPidana dan menghukum terdakwa dengan pidana penjara selama 2 (dua) tahun. Tujuan penerapan hukum terhadap Anak Sebagai Pelaku Tindak Pidana Pencurian 
Dengan Kekerasan Dalam Putusan Nomor : 42/Pid.Sus Anak/2017/PN.Mdn antara lain yakni tujuan pemidanaan yang bermaksud pembalasan, tujuan pemidanaan yang bermaksud pencegahan (prevensi), tujuan pemidanaan yang bemaksud keadilan masyarakat dan tujuan pemidanaan yang bermaksud memberikan perlindungan terhadap kepentingan Anak atau Terdakwa.

\section{DAFTAR PUSTAKA}

Amali, Z. (2014). Metode Penelitian Hukum, Jakarta; Sinar Grafika.

Amiruddin \& Asikin, Z. (2004). Pengantar Metode Penelitian Hukum, Jakarta: Raja Grafindo Persada. Moeliono, A.M. (1988). Kamus Besar Bahasa Indonesia, Jakarta: Balai Pustaka.

Arifin, S. (2011). Falsafah Hukum, Medan: Uniba Press.

Arief, B.N. (2001). Masalah Penegakan Hukum dan Kebijakan Penanggulangan Kejahatan, Bandung: PT. Citra Aditya Bakti.

Hidayat, B. (2014). Pemidanaan Anak Di Bawah Umur, Surabaya: P.T Alumni Bandung.

Kancil, C.S.T. (1989). Pengantar Ilmu Hukum dan Tata Hukum Indonesia, Jakarta: Balai Pustaka.

Kanter, E.Y., et.al, (1982). Asas-Asas Hukum Pidana di Indonesia, Jakarta: Alumni AHM-PTHM.

Gultom, M. (2006). Perlindungan Hukum Terhadap Anak, Bandung: Refika Aditama.

Gultom, M. (2010). Perlindungan Hukum Terhadap Anak, Cetakan Kedua, Bandung: P.T.Refika Aditama.

Hakim, A., dan Tan K., (2013), Peranan Polri dalam Penanggulangan Tindak Pidana Pencurian oleh Anak (Studi di Wilayah Hukum Kepolisian Resort Kota Medan), Mercatoria, 6 (2): 145-175

Hamzah, A. (1993). Sistem Pidana dan Pemidanaan Indonesia, Jakarta: Pradnya Paramit.

Hamzah, A. (2005), Hukum Acara Pidana Indonesia, Jakarta: Sinar Grafik

Ginting, H. \& Muazzul (2018). Peranan Kepolisian dalam Penerapan Restorative Justice terhadap Pelaku Tindak Pidana Pengeroyokan yang Dilakukan oleh Anak dan Orang Dewasa, Jurnal Ilmiah Penegakan Hukum, 5 (2): 32-40.

Kartanegara, S. (1998). Hukum Pidana Kumpulan Kuliah, Jakarta: Balai Lektur Mahasiswa.

Kartono, K. (1992). Patologi Sosial 2 Kenakalan Remaja, Jakarta: Rajawali Pers.

Kusumaningrum, S. (2014). Penggunaan Diskresi dalam Proses Peradilan Pidana, Jakarta: UI Press.

Djamil, M.N. (2013). Anak Bukan Untuk Dihukum, Jakarta: Sinar Grafika.

Harahap, M.Y. (2005). Pembahasan dan Penerapan KUHAP, Jakarta: Sinar Grafika.

Moeljatno. (2002). Asas-Asas Hukum Pidana, Jakarta: Rineka Cipta. Moeliono, Anton M., 1988, Kamus Besar Bahasa Indonesia, Jakarta: Balai Pustaka.

Muladi \& Arif, B.N. (2005). Teori-teori dan Kebijakan Pidana, Bandung: Alumni.

Rahardjo, S. (1998). Bunga Rampai Permasalahan Dalam Sistem Peradilan Pidana, Jakarta: .Pusat Pelayanan Keadilan dan Pengabdian Hukum.

Mubarak, R. \& Trisna, W. (2012). Buku Ajar Hukum Kejahatan Anak, Medan: Medan Area University Press.

Sidabutar, R. \& Suhatrizal. (2018). Perlindungan Hukum terhadap Anak yang Melakukan Tindak Pidana Pencabulan pada Putusan No.2/pid.sus/2014PN.Mdn. Jurnal Ilmiah Penegakan Hukum, 5 (1): 22-31.

Sinaga, S.M., dan Elvi Z.L., (2010), Perlindungan Hukum terhadap Anak Yang Melakukan Kejahatan dalam Persidangan Anak, Mercatoria, 3 (1): 52 - 57

Siregar, B. (1986). Keadilan Hukum Dalam Berbagai Aspek Hukum Nasional, Jakarta: Rajawali.

Siregar, M. (2005). Perdagangan International dan Penanaman Modal: Studi Kesiapan Indonesia dalam Perjanjian Investasi Multilateral, Medan: Sekolah Pascasarjana Universitas Sumatera Utara.

Sunggono, B. (1995). Metodologi Penelitian Hukum, Suatu Pengantar, Jakarta: Penerbit PT Raja Grafindo Indonesia.

Sunggono, B. (2011). Metodologi Penelitian Hukum, Jakarta: PT.Raja Grafindo Persada.

Vardiansyah, D. (2008). Filsafat Ilmu Komunikasi: Suatu Pengantar, Jakarta: Indeks.

Waluyadi. (2009). Hukum Perlindungan Anak, Bandung: Mandar Maju.

Zai, A., Taufik S., dan Dedy I., (2011), Perlindungan Hukum Terhadap Anak yang Berhadapan dengan Hukum dalam Sistem Peradilan Anak, (Studi pada Wilayah Hukum Polres Nias), Mercatoria, 4 (2): 86-103

B. Perundang-undangan

Undang-Undang Dasar 1945

雷http://mahesainstitute.web.id/ojs2/index.php/jehss mahesainstitut@gmail.com 
Kitab Undang-Undang Hukum Pidana Nomor 1 Tahun 1946

Undang-Undang No. 11 tahun 2012 Tentang Sistem Peradilan Pidana Anak

Undang-undang Nomor 35 Tahun 2014 Tentang Perubahan Atas Undang- undang Nomor 23 Tahun 2002 tentang Perlindungan Anak

C. Internet

https://www.researchgate.net/publication/50371518_FAKTOR_PENYEBAB_ANAK_MELAUKAN_TINDAK_ PIDANA_Studi_di_Lembaga_Pe masyarakatan_Anak_Blitar diakses 10-03-2018 jam 10.30 WIB.

https://siswatibudiarti.wordpress.com/2010/12/23/kenakalan-remaja-bentuk-penyebabdan-cara-mengatasinya diakses tanggal 10 Maret 2018 Pukul 11.40

http://internetsebagaisumberbelajar.blogspot.com/2010/07/pengertian- penerapan.html?m=1 diakses pada 21 Juli 2018, Pukul 17.50 Wib.

http://hukum-on.blogspot.com/2012/06/pengertian-hukum-menurut-para- ahli.htmldiakses pada 21 Juli 2018, Pukul 18.05 Wib 